\title{
Renegotiating Scottish Nationalism after the 2014 Independence Referendum
}

Le nationalisme écossais à l'épreuve du référendum d'autodétermination

\section{Emerence Hild}

\section{(2) OpenEdition \\ 12 Journals}

Electronic version

URL: http://journals.openedition.org/etudesecossaises/1134

DOI: 10.4000/etudesecossaises. 1134

ISSN: 1969-6337

Publisher

UGA Éditions/Université Grenoble Alpes

\section{Printed version}

Date of publication: 25 April 2016

Number of pages: 151-166

ISBN: 978-2-84310-324-7

ISSN: 1240-1439

Electronic reference

Emerence Hild, "Renegotiating Scottish Nationalism after the 2014 Independence Referendum", Études écossaises [Online], 18 | 2016, Online since 01 January 2017, connection on 15 March 2021. URL: http://journals.openedition.org/etudesecossaises/1134 ; DOl: https://doi.org/10.4000/ etudesecossaises. 1134 


\section{Renegotiating Scottish Nationalism after the 2014 Independence Referendum}

On 18 September 2014, Scots were invited to answer the following question: "Should Scotland be an independent country?" A majority of people rejected independence by a $55.25 \%$ to $44.65 \%$ vote. ${ }^{1}$ The turnout was just under $85 \%$ and the victory of the no camp was larger than had been expected regarding previous polls. Though the results meant that the 307 year old union between England and Scotland was preserved, the United Kingdom general election a few months later, on 7 May 2015, brought significant gains to the Scottish National Party. The SNP won 56 seats out of 59 in Scotland, thus outshining the three mainstream parties, including the Labour Party which had long been Scotland's first party. This situation begs a number of questions as to the viability of the links between Scotland and the rest of the United Kingdom, and-on a larger scale - as to the durability of the current system wherein four distinct nations with their own features and identities co-exist inside a multi-national overarching entity.

The campaign for the Scottish independence referendum was a surprisingly long one. It started in May 2012 with the launch of Yes Scotland, quickly followed by the launch of Better Together, and came to an end on 18 September 2014. Considering the length of this campaign, the diversity of media involved and the variety of arguments put forward by each side, it can be seen as rather striking that the concept of national identity should not have been discussed in more length during the pre-referendum campaign. Pro-independence supporters especially seem to have avoided the usual rhetoric of nationalist discourse during the campaign. In broad terms, this refers to an ideological discourse focused on the nature of the nation and its legitimacy as the main foundation for the state's sovereignty. As this article argues, Better Together campaigners paradoxically seemed more willing to use patriotic arguments than their opponents. It is undeniable though that the question

1. Results available on $<$ http://scotlandreferendum.info/ $>$. 
of identity was only touched upon and never examined as a major issue either by political parties or the two umbrella campaign groups. This is all the more surprising that the referendum campaign could have provided an ideal platform to have a debate about the state and future of Scottish and British identities. Nonetheless, the SNP's reluctance to insist on the affirmation of a strong Scottish identity or to emphasize its cultural specificities as part of its rhetoric and political strategy is not new to Scottish politics and might go some way to explaining the predominance of economic issues in the referendum campaign (Duclos, 2014).

Traditionally, Scottish politicians agree that Scottish identity is primarily a political, open and inclusive form of identity (Camp-Pietrain, 2014, p. 92). This vision is expressed through the concept of civic nationalism, a concept largely used by Scottish political elites to talk about the nation. However, studies have recently highlighted the discrepancy between the reality of Scottish people's perception of their national identity and the vision put forward by political elites (Leith \& Soule, 2011). Beyond this initial problem also lies a deeper issue, linked to the multiplicity of national identities and nationalisms in the United Kingdom. If we take the term national identity to mean both the set of multidimensional features (linguistic, cultural, historical, etc.) usually linked to a specific geographical entity - in this case Scotland - and people's inner feelings, individual as well as collective, of belonging to this particular territory then it both refers to the exterior and/or abstract signs of Scotland's existence as a nation and to the subjective agreement of its people to recognize Scotland as a coherent whole and possibly as part of their own identity. Nationalism also faces a plurality of definitions. One possible way to understand nationalism in Scotland or the United Kingdom is to see it as the political expression of Scottish and British national identities, through discourse and actions. Nationalism, in that particular sense, can be seen as one of the means by which identities are constructed and passed on. This theoretical background raises the question of the possibility for Scottish people to combine multi-layered identities and the question of the compatibility between nationalist discourses in Scotland and Britain outside the antagonistic aims of the SNP (Scottish independence) and British nationalism (status quo).

This article aims at examining the content and limitations of nationalists' and Unionists' competing visions of Scottish national identity in the specific light of their campaign discourse in the months before the 2014 referendum. It will focus on the particular treatment of identity issues during the campaign and argue that the close analysis of campaign productions actually reveals the existence of an underlying questioning about territorial attachments in Scotland, about Scottish and British 
nation-building and about political views of national identities in the United Kingdom.

\section{Civic nationalism in Scotland}

Many studies of nations and nationalism resort to the dichotomy between ethnic and civic nationalism (see Smith, 1991; Ignatieff, 1993). According to Jonathan Hearn:

[It] has been common to make a distinction between "ethnic" and "civic" forms of nationalism, the former involving beliefs in biological and cultural essentialisms, and the latter involving commitments to ideas of citizenship and the rule of law. (Cited in Kiely, Bechhofer \& McCrone, 2005b.)

Ethnic nationalism puts the emphasis on ethnic or cultural features such as one's language or religion, common descent, a shared history or a shared territory for example. The aim of ethnic nationalism is normally to obtain self-governance through the recognition of the nation's particular features. It is considered as an exclusive type of nationalism, meaning that only people with the right ethnic qualities or descent have a right to claim their belonging to the nation. It is opposed to civic nationalism which is based on the idea that people can willingly become part of the nation as long as they adhere to its core values and take part in the life of the society. It is a form of nationalism that has more to do with social ties, the existence of a social contract between the members of a given society and their attachment to the country's institutions than it has to do with cultural and ethnic elements. This particular type of nationalism exemplifies Ernest Renan's assertion that the nation is "a daily plebiscite". ${ }^{2}$ The civic notion of the nation suggests that belonging to a nation is first and foremost a question of choice and it is linked with the notions of democracy, citizenship and social justice. A remark about the terminology used in this article should be added here. The term cultural is highly ambiguous when related to the question of nationalism as has been shown by Rogers Brubaker (1998) for instance. In this article the adjective cultural will be used to describe the set of elements related to our understanding of ethnic nationalism (language, tradition or folklore for instance). The two concepts of civic and cultural nationalism should therefore not be conflated, even more so as the concept of cultural nationalism can be defined in its own right outside the civic/ethnic dichotomy.

2. Ernest Renan, Qu'est-ce qu'une nation?, 1882. 
The division between ethnic nationalism and civic nationalism can undoubtedly be questioned. The political theorist Bernard Yack for example sees in the civic/ethnic dichotomy a myth, that of consent versus descent (Bechhofer \& McCrone, 2015, p. 162) while Rogers Brubaker sees it as "a Manichean view that there are two kinds of nationalism, a good, civic kind and a bad, ethnic kind" (1998). Nevertheless it seems to be the basic conceptual means to understand the politics of national identity in Scotland today. Indeed, "the Scottish case seems to provide a good instance of [...] a civic, residential basis for belonging. [...] This is a view which runs across the political divide in Scotland, including the Scottish National Party" (Kiely, Bechhofer \& McCrone, 2005b). As Nathalie Duclos also underlines: "La conception de la citoyenneté écossaise par le SNP, fondée avant tout sur le principe de la résidence, se veut le reflet de son ancrage dans cette tradition civique." (2014, p. 151)

In the above statements, Scottish nationalism appears as firmly civic. On its website, the Scottish government defines Scottish national identity as follows:

Scotland's national and cultural identity is defined by our sense of place, our sense of history and our sense of self. It is defined by what it means to be Scottish; to live in a modern Scotland in a modern world; to have an affinity to Scotland; and to be able to participate in Scottish society. ${ }^{3}$

It is interesting to note that this vision of Scottish national identity does not refer to any national figures, national symbols or historical landmarks. It rather puts residency and a willingness to share social ties and duties with other members of the Scottish society at the heart of Scottish national identity. Two remarks can be made: first, even though the Scottish National Party is rightly to be seen as a nationalist party in the sense that its political aim is to gain independence, its project is not expressed through the rhetoric of ethnic and cultural symbolism. This is an important characteristic of the nationalist discourse in Scotland. Second, the recognition and defense of Scottish identity is not the sole privilege of the SNP. The vision of the Scottish nation as a coherent whole with innate specificities is rather shared among the Scottish political community and there seems to be little debate as to the civic aspect of the Scottish nation.

What follows from this definition is the fact that civic nationalism relates to a number of universal values and in that sense could as well be used to express the political creed of other Western countries such as

3. Scottish Government, "National Identity: We Take Pride in a Strong, Fair and Inclusive National Identity". Available on <www.gov.scot/About/Performance/scotPerforms/outcomes/nat Identity>. 
France. ${ }^{4}$ Besides, civic nationalism - as usually understood in the Scottish context - seems to deny the multiplicity of referential elements taken into account by people to construct their personal identity. It reduces national identity to a set of ideological values and principles while overlooking the multidimensional aspect of Scottish identity by disregarding the influence of cultural attributes over people's perception of their national identity. The complexity and multiplicity of feelings of identity in Scotland and the United Kingdom means that Scottish and British national identities should not be exclusively represented through the prism of the civic/ethnic dichotomy but as complex territorial identities. Indeed, considering the absence of ethnic and cultural elements to define Scottish (or British) national identities in the rhetoric of civic nationalism, it is assumed that the fundamental attribute for an individual to be able to claim his Scottishness is the fact that he is a Scottish resident. In other words, "the Scottish modernist interpretation put forward is one of Scottishness as a territorial, civic-based form of identity, whereby an individual resident in Scotland can claim to be Scottish" (Leith \& Soule, 2011, p. 4). Civic nationalism directly points at the importance of territoriality in the construction of people's national identity. The nation then is a community of people sharing a particular territory. But civic nationalism's vision of territoriality is restricted in the sense that it equates it to residency and makes it one of the most, if not the most, legitimate aspects for one to make the conscious choice of adhering to the nation. A different view of territory in the context of national identity could be underlined, according to which territorial entities help people locate themselves not only on a physical level but also on the subjective level of their attachment to the abstract attributes of the nation.

Paradoxically, territorial identities should not be conceived as a purely spatial attachment. They rely on a greater number of referential elements such as a particular language, specific traditions or a distinct culture. Territorial identities are thus "territorial" in the sense that they spatialize a full set of abstract elements. By giving a concrete location to nontangible elements territorial identities make it easier for individuals to apprehend these referential points. Territorial identities must therefore be understood as the individual's realization that he is attached to a given territory because of its multiple specificities. In social and geographical terms, this means that people can develop a sense of belonging to a given

4. However, in several parts of Europe the mounting influence of far-rights parties, including UKIP in the United Kingdom, actually seems to reveal an increasing criticism towards these values and the civic basis of integration and nation-building in these countries. 
territory that is related to their affection for the territory's specific features as well as for abstract elements they associate with the region.

There is undeniably a wide consensus in Scotland as to the fact that Scotland is a nation and that its political creed rests on the ideals of democracy, social justice and inclusiveness. The above reflection nevertheless stresses the fact that this apparent consensus does not prevent the notion of civic nationalism from being questioned. This is one of the reasons why it is important to contrast the theoretical definition of civic nationalism to the actual treatment of identity issues by political leaders and campaign groups during the referendum campaign. To what extent did campaign messages comply with the traditional notion of civic nationalism? How did political figures manage to play with the notion in order to promote their own vision of Scotland's future?

\section{Scottish nationalism and the referendum campaign}

If we look closely at the way identity issues were dealt with during the referendum campaign, a few elements can be underlined. First, it is important to note that few campaign productions were devoted to the question of Scottish national identity. Indeed, issues such as the economy, the health care system or Scotland's relations to Europe were at the centre of political debates, leaving at the periphery identity related problems. But the campaign groups' and political parties' campaigns were not limited to the speeches made by a number of influential figures (either from the political, business or cultural stage) on important meetings. Their campaigns also took place on a daily basis, on the streets through canvassing and leafletting as well as on the Internet. The study of campaign documents including web infographics, leaflets, campaign ads (posters, video clips, etc.) or pictures from campaign meetings ${ }^{5}$ show that, even though the campaign discourse of political figures did not make many references to Scottish and British national identities, Yes Scotland and Better Together campaigns made use of national symbols. In other words, even though national identities were not frequently spoken of as such, they were implicitly mentioned through the use of these symbols sometimes indicative of campaign groups' particular visions of British and Scottish identities. Second, there was a fundamental difference between pro-independence supporters who put aside patriotic and nationalistic arguments because they wanted voters to focus on concrete elements such

5. Available on the Scottish Political Archive website: <www.scottishpoliticalarchive.org.uk/wb/>. 
as the economy rather than on the more emotional issue of patriotic pride and Unionists who emphasized their attachment to Scotland as a nation.

Nicola Sturgeon in one of her speeches underlined the fact that:

Contrary to what many outside observers might imagine, the debate we are having is not about national identity. Scotland, like most modern European countries, is a melting pot of different identities: Scottish, British, Pakistani, Irish, Polish and many more besides. (2013)

This idea pertains to the fact that "nationhood or Scottish identity is not the motive force for independence" (ibid.). The idea of Scottish people's sense of national identity was seen as secondary but not as being problematic, in part because of the country's positive vision of multiculturalism.

Naturally, Yes Scotland supporters appropriated symbols such as the national flag or tartan kilts. Pictures of campaign meetings or independence rallies show that many people used these symbols as exterior signs of their support for Scottish independence. In the end, Yes Scotland, despite the fact that it rejected traditional ethnic and cultural forms of nationalism and promoted a multi-cultural vision of Scottish society, put forward such elements, mostly on the Internet. For example, the Yes Scotland social networks cover picture by artist Stewart Brenmer represented a Scottish flag and a girl wearing a tartan scarf and holding a thistle. Their campaign motto "Scotland's Future in Scotland's Hands" can also be read as an implicit reference to the rights of nations to selfdetermination which is an important element of discourse in traditional forms of nationalism promoting self-governance on the basis of ethnic or cultural features. However, the campaign for the Scottish referendum did not encourage pro-independence supporters to put aside their civic vision of national identity and rely on more traditional nationalist arguments. SNP leaders as well as other Yes Scotland prominent figures were consistent in pushing forward a vision of Scotland defined as a civic nation and promoting a society based on the shared values of social justice and democracy. As Alex Salmond put it in his speech outlaying his programme for government:

The real debate is how to create a prosperous country and a just society. Our attitude towards the disadvantaged and vulnerable. Our welcome for people who want to settle here. Our relationship with Europe and the rest of the world. Our strength as a society to which we all contribute. (Scottish Government, 2013)

Didier Revest provides another example that emphasizes the strength of this vision of Scottish national identity, the vision of an identity based on shared moral values and political principles. Referring to an interview 
of Blair Jenkins, the former chief executive of Yes Scotland, he states: " $[\mathrm{He}]$ has even explained that there is a definable set of 'Scottish values' which are 'distinct from values elsewhere in the UK'. To him, importantly, this difference is the basic reason why Scotland must leave the UK." (Revest, 2014) Yes Scotland did not base its campaign on a debate about the nature of the Scottish nation but put forward its members' long-time belief in civic nationalism. What this implies is that Scottish national identity was defined by Yes Scotland members as a socio-political identity, equating Scottishness to a set of values and a yearning for a better and more just society, which is in keeping with the rhetoric of civic nationalism.

A more striking element considering the fact that Yes Scotland was set up to lead the campaign in favour of Scottish independence is the fact that its members acknowledged the existence and the strength of people's feelings of Britishness. Contrary to Better Together members who, as we will see, tended to downplay the importance of Britishness as a feeling of national identity, Yes Scotland shared a positive outlook on the question of people's attachment to Britain. Nicola Sturgeon mentioned the "social, family and cultural heritage that makes up such a [British] identity" (2013). According to her it would be "sperfectly acceptable' [...] for someone to think of themselves as British and yet support Scotland's withdrawal from the UK" (Jack, 2013). The idea that Scottish people can feel a certain degree of British identity was not rejected. This might be seen as a simple way to avoid social and political issues, should a no vote win at the referendum. Or it could be seen as a way to attract undecided voters by asserting the possibility for them to keep a sense of British identity in an independent Scotland. Nevertheless, this particular position begs the question of the definition of Britishness. Is it a mere symbolic form of identity resulting from a long-time shared history?

If we now look at Unionists' vision of Scottish and British identities we can see that it both shared similarities and differences with proindependence supporters' vision. Gordon Brown' speech on the eve of the referendum provides an example of the use of patriotism in the Better Together campaign. The repetition of the word "proud" eight times by the former Prime Minister in his speech highlights his strong affirmation of Scottish admiration (Brown, 2014). Though the passionate tone of the speech was not typical of the Better Together campaign, other prominent unionist figures such as David Cameron and Alistair Darling also used the notions of pride and patriotism in speeches, articles or on TV. For instance, the British Prime Minister declared a few days before the vote: "Scotland is a proud, strong, successful nation." (Dearden, 2014) Through these elements of speech, the Better Together campaign acknowledged 
the specificity of Scotland's national identity. Moreover it related it to cultural elements: pride in the nation's heroes and famous people such as Adam Smith or Keir Hardie, pride in the nation's history and achievements or love of the country's particular features (Cameron, 2012). As a consequence it is possible to say that Better Together leading figures put forward a vision of the Scottish nation different from that defined by Yes Scotland. Here, in contrast to the socio-political vision of Yes Scotland members, Scottish national identity is presented as a cultural identity.

The United Kingdom was simultaneously shown as a family of nations (to take up a term repeatedly used by David Cameron in his speeches). Using the term "family of nations" instead of "nation" alone to describe the United Kingdom can be seen both as a way to differentiate British and Scottish identities and as a way to highlight the inherent link that unites the two. In any case, it connects with the idea of national identity. It is possible to note that Better Together leaders often referred to the United Kingdom as "our country," thus offering a counterpart to Yes Scotland's habit to refer to Scotland as "our nation". Another important aspect of the Better Together message concerning British and Scottish national identity is that they are fully compatible. As Alistair Darling explained:

This question of multiple identities is something Scots have been comfortable with for many years. It's entirely possible to be a patriotic Scot and be wholly at ease with being British. That's been the position for most of us for the last few centuries. In a typically unplanned way, this has become one of the UK's great strengths. There is more than one way of being Britishwhether you feel English, Welsh, Northern Irish or Scottish first, you can be British too without contradiction. (2013)

David Cameron also underlined the possibility for Scottish people to combine both Scottish and British feelings of identity, saying that "[you] can be proud of your Scottishness, proud of Scottish nationhood, proud of what Scotland stands for, proud of Scottish history but still believe in being part of the United Kingdom" (2014).

Being part of the United Kingdom is presented in that sense as a conscious choice made by people who feel attached to the British state, and British identity becomes a sort of overarching identity superimposed to other national identities. Even though Better Together tried to insist on its members' attachment to Scotland, it nevertheless conveyed a message designed to reconstruct a positive image of Britain and British identity. This image of Britishness is based on the idea that it consists in a set of values: "British values. Fairness. Freedom. Justice." (Dearden, 2014) These values belong to a civic vision of the nation as defined above. As 
for Yes Scotland, Better Together therefore resorted to the discourse of civic nationalism, only this time to convey a civic vision of the British nation instead of the Scottish nation.

\section{Beyond Scottish nationalism: identities in question}

The use of national symbols by both campaign groups indicates that the question of national identity was not erased from the campaign but used as a means to implicitly reconstruct their own image of Scottish and British national identities to appeal to the electorate rather than as an issue in itself. The discourse of national identity in the Better Together campaign for instance remained highly politicized. Indeed, it could be argued that the Better Together campaign took advantage of the fact that the Yes Scotland campaign did not wish to discuss national identity issues to adopt a patriotic oriented discourse. Looking at occurrences of patriotic statements in the discourse of Better Together supporters, there was undeniably and unsurprisingly a political ambition linked to it: appealing to Scottish voters with a strong sense of national identity by showing their similar support for the Scottish nation and rekindling a sense of British identity among all Scottish people. Whether in the end this strategy played a part in the no victory is open to question. According to the Ipsos-MORI poll released on the day of the referendum, only $19 \%$ of the voters said they were motivated by their feeling of identity (What Scotland Thinks, 2014).

In both campaigns, the question of national identity was used to some extent as a means to discredit the opposite side. Better Together supporters accused Yes Scotland of breaking British "family ties" and Yes Scotland insisted on Unionists' refusal to consider Scotland as a successful nation capable of governing itself. After having studied the treatment of national identity issues by the Yes Scotland and Better Together campaigns, it is possible to argue that the debates remained centred on a political vision of Scottish and British national identity. The issue of British territorial identities was either overlooked or given a political overtone to convey a message during the campaign, so that a real exploration of the issues raised by the evolution of the relations between British different nations was made impossible. The campaign message of supporters of either Scottish independence or the Union only briefly highlighted elements of redefinition of British and Scottish identities. Attempts by the two campaign organisations and political parties at convincing the electorate either to vote yes or no resulted in no-supporters being more anxious to assert their Scottish identity than their British belonging. As for pro- 
independence supporters, the fact that they intentionally avoided the issue of national identity resulted in the impossibility for national identity issues to be placed at the centre of the political stage.

In order to understand the problems raised by the absence of a fullfledged debate about Scottish and British identities or a confrontation of pro-independence and unionist nationalist discourses, the conflicting views highlighted before can be rephrased as follows. To Scottish nationalists, the fact that the United Kingdom is a political entity linking together four different nations meant that Scottish independence would not impact people's feeling of attachment to Britain because all four nations would still share the same ties as neighbour states. This vision of British identity implies that, even if Scotland had become independent, the abstract bond between Scotland and the rest of the United Kingdom, what Benedict Anderson famously calls an "imagined community" (1983), could have been preserved. At the same time, it also suggests that Scottish national identity would not be impaired by the country's removal from the United Kingdom and is independent from Scottish people's possible attachment to the United Kingdom as a whole. To Unionists on the contrary, the fact that Scotland is part of the British state means that the two territorial identities are necessarily linked and that Scotland's independence would sever this link. In spite of the differences between these competing visions, both therefore seem to assert a certain degree of compatibility between people's feeling of Scottish identity and British belonging.

Although Unionists did not insist on describing the United Kingdom as a nation and British identity as a shared feeling among all British people, the fact that they defined it in terms of principles and values reveals their particular take on the issue of multiple identities in the United Kingdom. Their attempt at reconstructing an image of British identity as "a strong, albeit non-ethnic identity, apart from and above that of the component parts" (Keating, 2009, p. 67) is reminiscent of the discourse of civic nationalism. This vision of Britishness comes into conflict with the nationalist vision of Scottish identity. According to Michael Keating:

[The] effort to promote national identities based on universal values confronts, not a Scottish identity based on exclusion and ethnicity, but a revived Scottish national identity based on exactly the same values and with a distinct European and global dimension. (2009, p. 69)

In other words, Scottish and British identities necessarily come into a conflict if they are both defined as civic, inclusive identities. Indeed, if Scottish identity represents a set of values and the possibility for people to live according to these values in Scotland, the British state cannot have 
a similar purpose without implying a sense of hierarchy between British and Scottish identities. To Scottish nationalists, Scottish and British identities cannot play the same role in people's identity construction so that defining them in a similar way necessarily creates a conflicting situation where Scottish and British identities become antagonistic. Didier Revest puts it differently when he says: "To a Scot who believes that Scotland is the bounded community of solidarity (otherwise known as the sharing community) he or she belongs to, the 'family' cannot mean the same as to someone who sees the UK as playing that role." (2014) For Unionist nationalists there is no inconsistency though considering the fact that their unionist project prevails over subnational particularities.

Is the break-up of Britain inevitable then? During the referendum campaign, yes-supporters made it clear that Scotland's independence would not mean the break-up of the United Kingdom but a redefinition of the relations between its states. On the contrary, Unionists heavily relied on the rhetoric of the break-up of Britain, forecasting the consequences this would have in Scotland and in the rest of the United Kingdom. Alistair Darling for instance stated: "We do not need to divide these islands into separate states in order to assert our Scottish identity" in his second televised debate against Alex Salmond, using the words "divide" and "separate" conveying a negative connotation to point to the need for the United Kingdom to stay united. Even though the results of the referendum were a clear no, the assumption that Britishness might be under threat or lack popular support in the United Kingdom cannot be unilaterally eluded. Nevertheless, beyond the question of people's actual feeling of attachment to Scotland and the United Kingdom as territorial, political and cultural entities, what is at stake is the political expression of Scottish and British nationalisms. These two conflicting views remain at the heart of the debate about the state and future of the United Kingdom.

Finally, we come to the same conclusion as Didier Revest in his recent book on the Scottish independence debate:

No discussion of the future of the UK will be final, at least, that is, for the foreseeable future, unless the very basis of what it means and should meanin terms of sharing community - is addressed, regardless of the objective differences between the said nations. Put differently, the debate will be as much about [the UK four nations] individually as about them collectively to do justice to the fact that many [...] still see no contradiction in belonging equally to more than just one political sphere. (2014, p. 148) 


\section{Conclusion}

The 2014 referendum put the question of the relation between Scotland and the rest of the United Kingdom at the heart of the political debate, in much the same way as the 1997 referendum on devolution had done before. The study of the referendum campaign from the specific angle of identity-related issues advanced above has revealed the complex picture of national identities and nationalism in contemporary Scotland. The campaign debates have shown the reluctance of British and Scottish politics to distance themselves from a civic conception of the British and Scottish nation. This is one of the main reasons why we find that yes and no supporters actually defended diverging visions of British and Scottish identities that were, as such, irreconcilable. Nevertheless, both campaign groups asserted the possibility for people to express several feelings of belonging at the same time, though they did not give the same explanation for these possibly multiple identities. To break the deadlock pro-independence supporters' and Unionists' conceptions of British and Scottish national identities seem to lead to, there seems to be a necessity for both identities to be taken out of the political context of the referendum and to be redefined so as to comply with the reality of people's feelings of belonging. As recent sociological studies show, for a majority of them this is a dual sense of belonging to the Scottish nation and the British state (see for example Bechhofer \& McCrone, 2015). In the end, the treatment - but lack of exploration - of identity issues during the campaign revealed the need for political actors to encourage multi-layered identities by redefining their vision and representation of Scottish and British identities.

One of the means by which multi-layered identities can truly be encouraged is by redefining Scottish national identity. Whether it is taken as an ideological ideal resting on the principles of civic nationalism or not, it takes root and shape in a well-defined territory, that of Scotland. The country, given its clear boundaries, makes it possible for its inhabitants to develop a feeling of belonging to Scotland and the Scottish nation. As a consequence, Scottish national identity can be redefined, to some extent at least, as a territorial form of belonging to a particular territory, not in terms of residency but in terms of subjective attachment to the said territory, that is to say as the adherence to a number of values, discourses, principles and cultural elements. Ethnic and cultural attributes do necessarily bear a symbolic quality that can be assimilated by the people living in a given territory and developing a sense of national identity. Scottish national identity can therefore be seen at least in part as a territorial identity choice made by people who become aware of their attachment to 
Scotland and what they identify as the founding features of the nation, both in terms of ideology and cultural attributes. Most importantly, Scottish identity is a multi-dimensional identity and escapes any definition that would reduce it to a single monolith.

The question of Scottish and British national identity is still a heated issue in the aftermath to the referendum. While all political figures agreed on the fact that the referendum would be a once-in-a-lifetime chance for Scottish people to change the way they are governed, the results of the 2015 general election and the upcoming referendum on the United Kingdom's membership to the European Union have already led the media to mention the possibility for another referendum on Scottish independence. Whether a new referendum takes place in a foreseeable future or not, and even if political figures still see national identities as a subsidiary issue, the question of Scottish and British identities and their relation to one another as well as that of the implications of people's feelings of national belonging will probably continue to stir public debate.

\section{Bibliography}

\section{Primary sources}

BRown Gordon, 2014 (17 September), "Speech on Eve of Scotland's Independence Vote", City A.M. Available on <www.cityam.com/14 11051570 /gordon-browns-better-together-speech-eve-scottish-inde pendence-referendum-vote-full-video $>$ (accessed 15 October 2014).

Cameron David, 2012 (16 February), "Speech on Scottish Independence". Available on <htpp://www.gov.uk/government/speeches/transcriptpm-scotland-speech $>$ (accessed 20 March 2015).

—, 2014 (3 July), "Prime Minister Speech at Rally for the Union Event". Available on <http://conservativefriendsoftheunion.com/2014/07/ 03/695> (accessed 20 March 2015).

DARLING Alistair, 2013 (10 July), "We Belong Together: The Case for a United Kingdom". Available on <www.bettertogether.net/blog/entry/ watch-alistair-darlings-lecture-live $>$ (accessed 15 October 2014).

Dearden Lizzie, 2014 (16 September), "Scottish Independence: Full Text of David Cameron's 'No Going Back' Speech”, The Independent. Available on <http://independent.co.uk/news/uk/scottish-independence/ scottish-independence-full-text-of-david-camerons-no-going-backspeech-9735902.html> (accessed 2 Febuary 2015).

Harvie Patrick, 2013 (10 January), "Perspective: Why a Yes Voter Needn't Be a Nationalist". Available on <www.yesscotland.net/perspective_why _a_yes_voter_needn_t_be_a_nationalist> (accessed 6 October 2014). 
JAck Ian, 2013 (24 August), "Nicola Sturgeon Interview: 'I Do Believe Scotland Can Be Better Off", The Guardian. Available on <www.the guardian.com/politics/2013/aug/24/nicola-sturgeon-scotland-betteroff $>$ (accessed 3 December 2014).

"Salmond \& Darling - The Debate," STV player, 5 August 2014. Available on <http://player.stv.tv/episode/2wvi/salmond-darling/> (accessed 15 October 2014).

"Scotland Decides: Salmond versus Darling", BBC iplayer, 25 August 2014. Available on <www.bbc.co.uk/iplayer/episode/b04g1w4s/scotlanddecides-salmond-versus-darling $>$ (accessed 15 October 2014).

Scotland OFFice, <www.gov.uk/government/topics/scotland> accessed 16 February 2015).

Scottish Government, n.d., "National Identity: We Take Pride in a Strong, Fair and Inclusive National Identity". Available on <www. gov.scot/About/Performance/scotPerforms/outcomes/natIdentity> (accessed 15 March 2015).

—, n.d., "Scotland's Referendum". Available on <www.scotreferendum. com/> (accessed 16 February 2015).

—, 2012 (January), Your Scotland, Your Referendum.

—, 2013 (3 Sept.), "Speech about Programme for Government". Available on <http://news.scotland.gov.uk/Speeches-Briefings/Speech-aboutProgramme-for-Government-3b3.aspx > (accessed 3 November 2014). _ 2013 (November), Scotland's Future: Your Guide to an Independent Scotland. Scottish Political Archive, 2006. <www.scottishpoliticalarchive.org. $\mathrm{uk} / \mathrm{wb} />$ (accessed 6 March 2015).

Sturgeon Nicola, 2012 (3 December), Building a Better Nation. Available on <http://www.scotland.gov.uk/news/speeches/better-nation-031212> (accessed 4 December 2014).

_, 2013 (3 January), Scotland and Europe. Available on <http://www. scotland.gov.uk/News/Speeches/Scotland-europe-25-01-2013> (accessed 4 December 2014).

—, 2013 (27 January), No More "What Ifs". Available on <www.scotsman. com/news/nicola-sturgeon-no-more-what-ifs-1-2761524> (accessed 15 April 2015).

What Scotland Thinks, n.d. <www.whatscotlandthinks.org>.

\section{Secondary sources}

Adamson Kevin \& Lynch Peter (eds), 2013, Scottish Political Parties and the 2014 Independence Referendum, Cardiff, Welsh Academic Press.

Anderson Benedict, 1983, Imagined Communities: Reflections on the Origin and Spread of Nationalism, London, Verso. 
Bechhofer Frank \& MaCrone David, 2015, Understanding National Identity, Cambridge, Cambridge University Press.

Brubaker Rogers, 1998, "Myth and Misconception in the Study of Nationalism", in J. Hall (ed.) The State of the Nation: Ernest Gellner and the Theory of Nationalism, Cambridge, Cambridge University Press.

Camp-Pietrain Edwige, 2006, La devolution : Écosse - Pays de Galles, Neuilly-sur-Seine, Atlante.

—, 2014, L'Écosse et la tentation de l'indépendance : le référendum d'autodétermination de 2014, Villeneuve-d'Ascq, Presses universitaires du Septentrion.

Duchos Nathalie, 2014, L'Écosse en quête d'indépendance : le référendum de 2014, Paris, Presses de l'université Paris-Sorbonne.

Grandjean Pernette (dir.), 2012, Construction identitaire et espace, Paris, L'Harmattan.

Guérin-PACe France, 2006, "Sentiment d'appartenance et territoires identitaires", L'espace géographique, vol. 35, no. 4, pp. 298-308.

Guermond Yves, 2006, "L'identité territoriale : l'ambiguité d'un concept géographique", L'espace géographique, vol. 35, no. 4, pp. 291-7.

IgnatiefF Michael, 1993, Blood and Belonging: Journeys into the New Nationalism, New York, Farra, Straus and Giroux.

Keating Michael, 2009, The Independence of Scotland. Self-Government and the Shifting Politics of Union, Oxford, Oxford University Press.

Kiely Richard, BechHofer Frank \& McGrone David, 2005a, "Whither Britishness? English and Scottish People in Scotland", Nations and $\mathrm{Na}^{-}$ tionalism, vol. 11, no. 1, pp. 65-83.

—, 2005b, "Birth, Blood and Belonging: Identity Claims in Post-Devolution Scotland", The Sociological Review, vol. 53, no. 1, pp. 150-72.

Leith Murray Stewart \& Soule Daniel P.J., 2011, Political Discourse and National Identity in Scotland, Edinburgh, Edinburgh University Press.

Leruez Jacques, 2000, L'Écosse, vieille nation, jeune État, Grozon, Éditions Armeline.

Leydier Gilles, 1998, La question écossaise, Rennes, Presses universitaires de Rennes.

Lynch Peter, 2002, SNP: The History of the Scottish National Party, Cardiff, Welsh Academic Press.

MaCrone David, 1992, Understanding Scotland: The Sociology of a Stateless Nation, London, Routledge.

Piтtock Murray, 2013, The Road to Independence? Scotland in the Balance, London, Reaktion Books.

REvest Didier, 2014, Independence for Scotland! Independence for Scotland? Theoretical and Practical Reflections on the 2014 Referendum and Its Possible Outcomes, Newcastle upon Tyne, Cambridge Scholars Publishing.

Smith Anthony D., 1991, National Identity, London, Penguin. 